\title{
Distribusi Defisiensi Glucose-6-Phosphate Dehydrogenase (G-6-PD) pada Berbagai Populasi Masyarakat di Indonesia
}

\author{
Distribution of Glucose-6-Phosphate Dehydrogenase (G-6-PD) Deficiency in Indonesian \\ Populations
}

\section{Fransiska Lanni}

Fakultas Biologi Universitas Atma Jaya Yogyakarta, Jl. Babarsari No. 44, Yogyakarta 55281, Indonesia E-mail: frlanni@yahoo.com

\begin{abstract}
Glucose-6-phosphate dehydrogenase (G-6-PD) deficiency is the most common human enzymopathy, nearly 400 different biochemical variants of the enzyme have been described worldwide. The heterogeneity of these abnormal hemoglobins are very extensive in some populations such as the results of malarial natural selection and the use as genetic markers for certain populations. As in others malarious areas in Southesat Asia, the presence of G-6-PD deficiency in most Indonesians might be prevalent. Nevertheless the frequencies and epidemiological distribution of these hereditary blood diseases among Indonesians has not been well known yet. This study have screened 2059 unrelated, apparently healthy adult blood samples from 17 different populations. The present investigation had shown that the G-6-PD deficiency was commonly found in lesser Sunda populations sampled, hold beyond Bali to the east in significant frequencies range from $5 \%$ to $13.5 \%$.
\end{abstract}

Key words : G-6-PD deficiency, genetic marker, malarial endemic, Indonesian populations

Diterima: 19 Mei 2003, disetujui: 20 November 2003

\section{Pendahuluan}

Defisiensi enzim glucose-6-phosphate dehydrogenase (G-6-PD), merupakan enzimopati herediter yang paling banyak dijumpai di dunia dalam frekuensi polimorfik. Kelainan genetik ini disebabkan oleh satu atau lebih mutasi di sepanjang kira-kira $18 \mathrm{~Kb}$ gen G-6-PD yang terletak pada lengan pendek kromosom X (Xp28), terdiri dari 13 exon dan 12 intron (Martini et al., 1986). Mutasi tersebut dapat menyebabkan enzim G-6-PD pada eritrosit kehilangan sebagian aktivitas katalitiknya (low activity) atau seluruhnya (no activity) (Beutler, 1993).

Sebagai katalisator utama dalam jalur metabolisme karbohidrat hexose monophosphate shunt (HMS), enzim G-6-PD sangat dibutuhkan dalam eritrosit karena HMS merupakan satu-satunya jalan pembentu nicotimamide adenin dinucleotide phosphat tereduksi (NADPH) dalam sel yang tida bermitokondria tersebut (Luzatto and Gordon Smith, 1999). NADPH dibutuhkan dalan metabolisme eritrosit sebagai donor elektro dalam berbagai jalur biosintesis dan untu regenerasi glutation tereduksi yang bertinda sebagai antioksidan potensial (Luzatto, 1995) Pada individu defisiensi G-6-PD keberadaa beberapa oksidan seperti obat antimalaria antipiretik dan senyawa isoraumil aka menyebabkan cadangan NADPH dalan eritrosit tersebut semakin sedikit dan tida mampu mempertahankan metabolisme Akibatnya terjadi hemolisis dari ringan sampa akut yang merupakan manifestasi klinis utam pada kasus defisiensi G-6-PD (Mehta, 1994). 
Di lain pihak mutan gen G-6-PD telah dilaporkan mempunyai keuntungan selektif terhadap invasi plasmodium, sehinggga gen mutan ini sangat umum dijumpai pada daerah endemis malaria. Pada eritrosit yang defisiensi G-6-PD, plasmodium tidak dapat bertahan hidup, karena kadar NADPH dan energi yang dihasilkan sangat sedikit ((Luzatto, 1979; Ganczakowski et al., 1995; Ruwende et al., 1995).

Diduga defisiensi G-6-PD diderita oleh sekitar 400 juta orang di seluruh dunia baik di daerah tropis maupun subtropis (Vulliamy et al., 1992). Beberapa penelitian tentang defisiensi G-6-PD telah dilakukan di Indonesia secara sporadis, di Jakarta misalnya diperkirakan frekuensinya berkisar 1 - 2,6\% (Surodi et al., 1979), di Jawa Tengah dijumpai sekitar 14\% pada individu laki-laki (Soemantri et al., 1995) dan di Maluku Selatan kira-kira 4,4\% (Suhartati et al., 2000). Sementara peta distribusi defisiensi G-6-PD secara keseluruhan di Indonesia belum diketahui saat ini, padahal data tersebut sangat penting dalam penataan sistem kesehatan masyarakat. Sebagai daerah endemis malaria, keberadaan defisiensi G-6PD di Indonesia diperkirakan cukup tinggi, sehingga dalam penelitian ini dilakukan penapisan gen defisiensi G-6-PD pada 17 populasi berbeda (dari 20 populasi yang direncanakan) yang dianggap cukup mewakili populasi Indonesia secara keseluruhan.

\section{Metode Penelitian}

\section{Sampel}

Populasi yang dikaji adalah 1. Batak, 2. Minangkabau, 3. Melayu Riau, 4. Palembang, 5. Bangka, 6. Jawa, 7. Tengger. 8. Dayak, 9. Banjar, 10. Minahasa, 11. Toraja, 12 Palu, 13. Bali, 14. Sasak, 15 Sumbawa, 16. Sumba, dan 17. Alor. Tiga populasi yang tidak terkoleksi sampelnya adalah Tetum (Timor Leste, dahulu Timor Timur), Amahai (Seram) dan Asmat (Irian Jaya), karena alasan keamanan akibat konflik sosial politik yang berkepanjang hingga penelitian ini berakhir. Jumlah sampel darah yang berhasil dikoleksi dari 17 populasi tersebut adalah 2059 yang berasal dari 844 orang laki-laki dan 1215 orang perempuan.

\section{Koleksi sampel}

Sampel darah diambil dari darah vena orang sehat dewasa sebanyak $5 \mathrm{ml}$ dengan bantuan vacumtainer (Terumo) yang telah berisi antikoagulan heparin. Jumlah sampel untuk tiap populasi di atas 100 orang (kecuali Bali) tidak ada hubungan keluarga satu sama lain dan dianggap mewakili populasi tersebut sampai tiga generasi ke atas. Sebelum dilakukan uji penapisan defisiensi G-6-PD, terhadap semua sampel darah telah dilakukan pemeriksaan indeks hematologis yang meliputi, kadar $\mathrm{Hb}, \mathrm{PCV}, \mathrm{MCV}, \mathrm{MCHC}, \mathrm{RBC}$, dan WBC.

\section{Penentuan aktivitas G-6-PD}

Untuk mendapatkan hasil yang akurat, aktivitas G-6-PD ditentukan dengan uji kualitatif maupun uji kuantitatif. Uji kualitatif meliputi teknik fluoresensi UV (Kit Sigma cat. no. 212) dan formazan ring spot test (Hirono, 1977), sedangkan uji kuantitatif dilakukan dengan spektrofotometri (kit Sigma cat. no. 210). Perpaduan ketiga teknik tersebut diharapkan dapat menjaring > 90\% kasus defisiensi G-6-PD di lapangan. Pada uji fluoresensi diukur intensitas pendaran bercak darah pada kertas saring di bawah sinar UV, jika pendaran tersebut terang berarti normal, redup $=$ defisiensi G-6-PD low activity (LA) gelap = defisiensi G-6-PD no activity (NA). Uji formazan ring spot test berdasarkan diameter lingkaran formazan yang terbentuk, normal jika diameternya > $7 \mathrm{~mm}$, defisensi G-6-PD LA jika $<7 \mathrm{~mm}$ dan defisiensi G-6-PD NA jika tidak ada diameter formazan yang terbentuk. Pada uji kuantitatif, aktivitas enzim dinyatakan normal jika nilainya berkisar 4,6 $\mathrm{U} / \mathrm{gHb}$, defisiensi G-6-PD LA = 2 - 4,5 U/g Hb dan jika $<2 \mathrm{U} / \mathrm{g} \mathrm{Hb}=$ defisiensi G-6-PD NA.

\section{Hasil dan Pembahasan}

Penapisan dengan metode fluoresensi UV (Gambar 1) terhadap 2059 sampel darah berhasil menjaring 108 individu yang dicurigai sebagai pengemban defisiensi G-6-PD yang terdiri dari 56 sampel defisiensi G-6-PD LA dan 52 sampel defisiensi G-6-PD NA. 
Selanjutnya penapisan dengan metode formazan ring spot test (Gambar 2) juga memperlihatkan hasil yang persis sama dengan metode fluoresensi UV baik pada defisiensi G-6-PD LA maupun G-6-PD NA. Hasil yang sama juga diperoleh pada uji kuantitatif seper yang diperlihatkan Tabel 1. dan hasil akhi penapisan dengan ketiga metode tersebu dirangkum pada Tabel 2.

Tabel 1. Rerata aktivitas G-6-PD pada eritrosit normal, defisiensi G-6-PD low activity dan no activity dengan metode spektrofotometrik.

\begin{tabular}{ccc}
\hline \multicolumn{1}{c}{ Kelompok sampel } & Jumlah Sampel & Aktivitas enzim G-6-PD (U/g Hb) \\
\hline 1. Normal & $\mathbf{1 6 4 2}$ & $7,9 \pm 2,7$ \\
a. Laki-laki & 662 & $7,5 \pm 1,9$ \\
b. Perempuan & 980 & \\
2. Defisiensi G-6-PD low activity & $\mathbf{5 6}$ & $2,9 \pm 0,7$ \\
a. Laki-laki & \multicolumn{2}{c}{$3,1 \pm 0,9$} \\
b. Perempuan & 41 & $0,4 \pm 0,2$ \\
3. Defisiensi G-6-PD no activity & $\mathbf{5 2}$ & $0,7 \pm 0,3$ \\
a. Laki-laki & 32 & \\
b. Perempuan & 20 & \\
\hline
\end{tabular}

Tabel 2. Distribusi defisiensi G-6-PD pada berbagai populasi Indonesia dengan metode fluoresensi UV, formazan ring spot test dan spektrofotometrik.

\begin{tabular}{|c|c|c|c|c|c|c|}
\hline \multirow{3}{*}{ Populasi } & \multirow{3}{*}{$\begin{array}{c}\text { Jumlah } \\
\text { sampel } \\
\text { yg diteliti }\end{array}$} & \multicolumn{4}{|c|}{ D E F I S I E N S I G-6-PD* } & \multirow{3}{*}{$\begin{array}{c}\text { Jumlah } \\
(\%)\end{array}$} \\
\hline & & \multicolumn{2}{|c|}{ Low activity } & \multicolumn{2}{|c|}{ No activity } & \\
\hline & & LK & PR & LK & PR & \\
\hline 1. Batak & 135 & 3 & 6 & 7 & 3 & $19(14,7)$ \\
\hline 2. Melayu & 115 & 0 & 0 & 0 & 0 & 0 \\
\hline 3. Minangkabau & 134 & 0 & 0 & 0 & 0 & 0 \\
\hline 4. Palembang & 108 & 0 & 2 & 2 & 0 & $4(3,7)$ \\
\hline 5. Bangka & 111 & 0 & 2 & 1 & 1 & $4(3,6)$ \\
\hline 6. Jawa & 125 & 1 & 0 & 0 & 0 & $1(0,8)$ \\
\hline 7. Tengger & 104 & 0 & 2 & 3 & 1 & $6(5,7)$ \\
\hline 8. Dayak & 130 & 0 & 3 & 2 & 3 & $8 \quad(6,1)$ \\
\hline 9. Banjar & 113 & 0 & 0 & 0 & 0 & 0 \\
\hline 10. Minahasa & 116 & 0 & 0 & 0 & 0 & 0 \\
\hline 11. Palu & 162 & 2 & 5 & 3 & 3 & $13(8,0)$ \\
\hline 12. Toraja & 127 & 1 & 4 & 2 & 2 & $9(7,2)$ \\
\hline 13. Bali & 82 & 2 & 4 & 3 & 2 & $11(13,5)$ \\
\hline 14. Sasak & 138 & 2 & 5 & 2 & 3 & $12(8,7)$ \\
\hline 15. Sumbawa & 118 & 0 & 3 & 3 & 1 & $7 \quad(5,9)$ \\
\hline 16. Sumba & 120 & 2 & 2 & 2 & 0 & $6(4,9)$ \\
\hline \multirow[t]{2}{*}{ 17. Alor } & 121 & 2 & 3 & 2 & 1 & $8 \quad(6,6)$ \\
\hline & & \multicolumn{2}{|c|}{41} & \multicolumn{2}{|c|}{20} & \\
\hline Jumlah & 2059 & \multicolumn{2}{|c|}{$56(51,8)$} & \multicolumn{2}{|c|}{$52(48,2)$} & 108 \\
\hline
\end{tabular}

\footnotetext{
* angka dalam kurung dalam persen.
} 


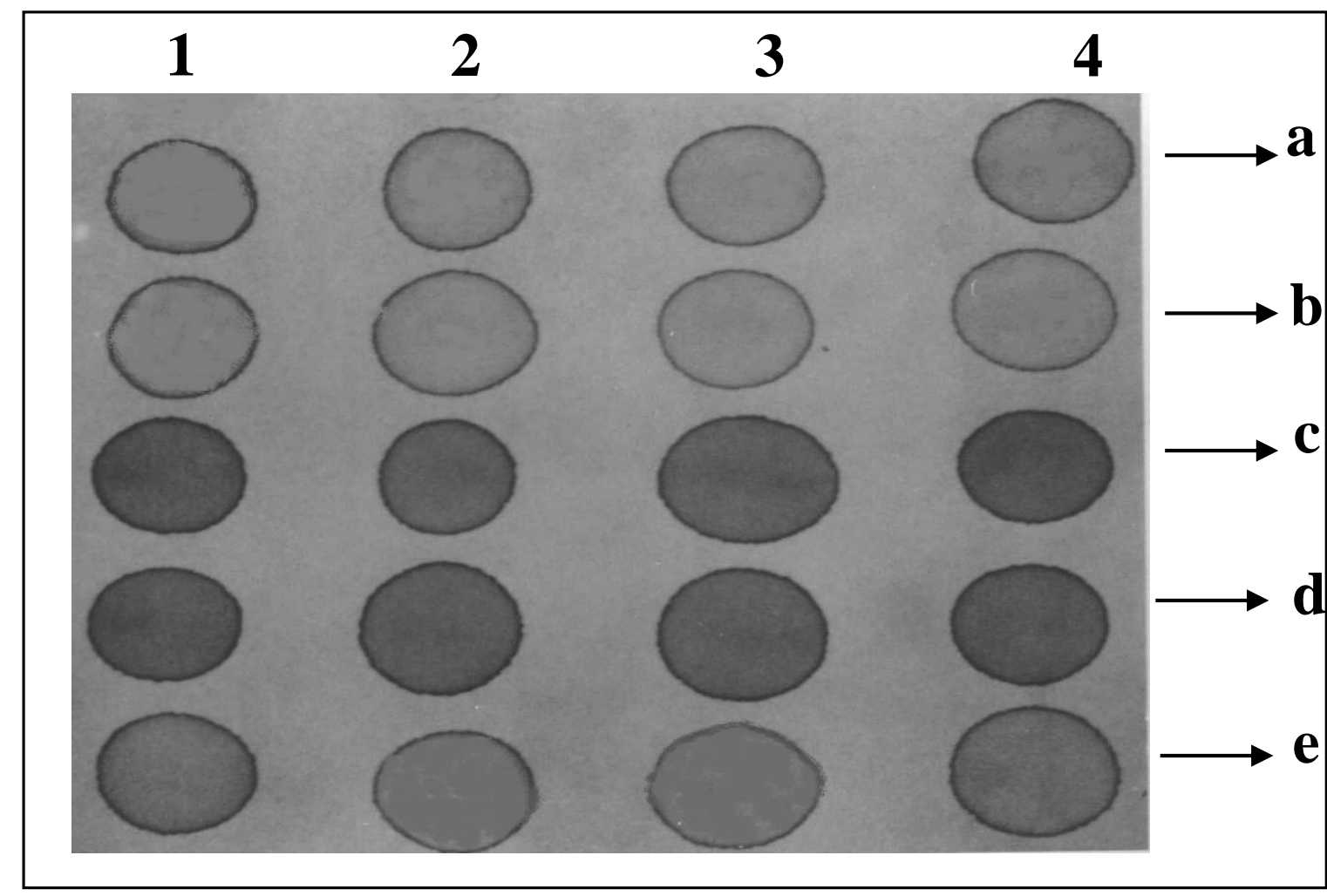

Gambar 1. Pola fluoresensi UV eritrosit defisiensi G-6-PD, dengan waktu inkubasi $1=0$ menit, $2=5$ menit, $3=10$ menit, $4=15$ menit. $a=$ kontrol negatif (eritrosit normal), $\mathrm{b}=$ eritrosit normal, $\mathrm{c}=$ kontrol positif (eritrosit defisiensi G-6-PD no activity), $\mathrm{d}=$ eritrosit defisiensi G-6-PD no activity, dan e = eritrosit defisiensi G-6-PD low activity.

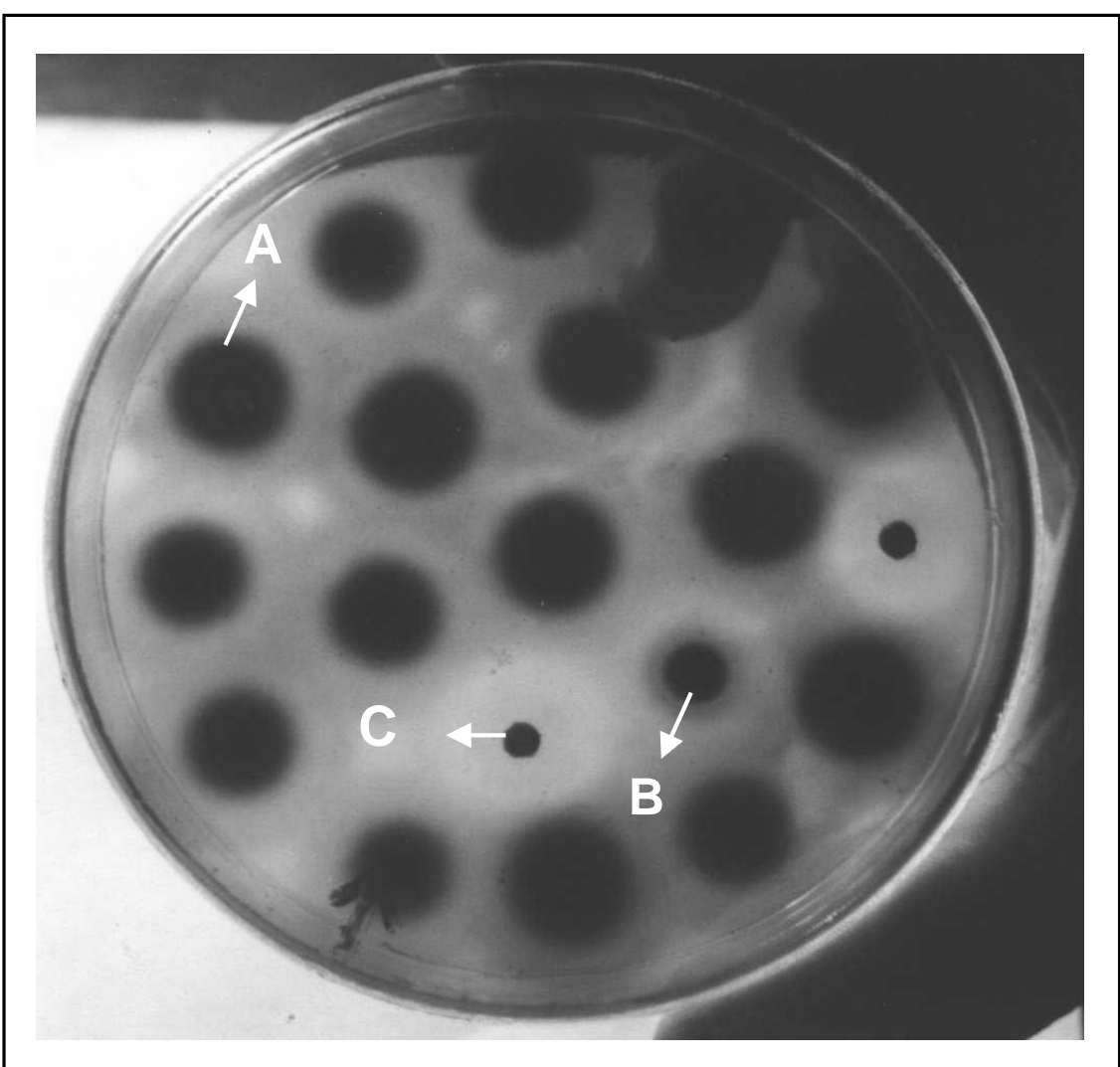

Gambar 2. Gambaran bercak formazan pada eritrosit defisiensi G-6-PD, $a=$ eritrosit normal. $b=$ eritrosit defisiensi G-6PD low activity dan $\mathrm{c}=$ eritrosit defisiensi G-6-PD no activity. 


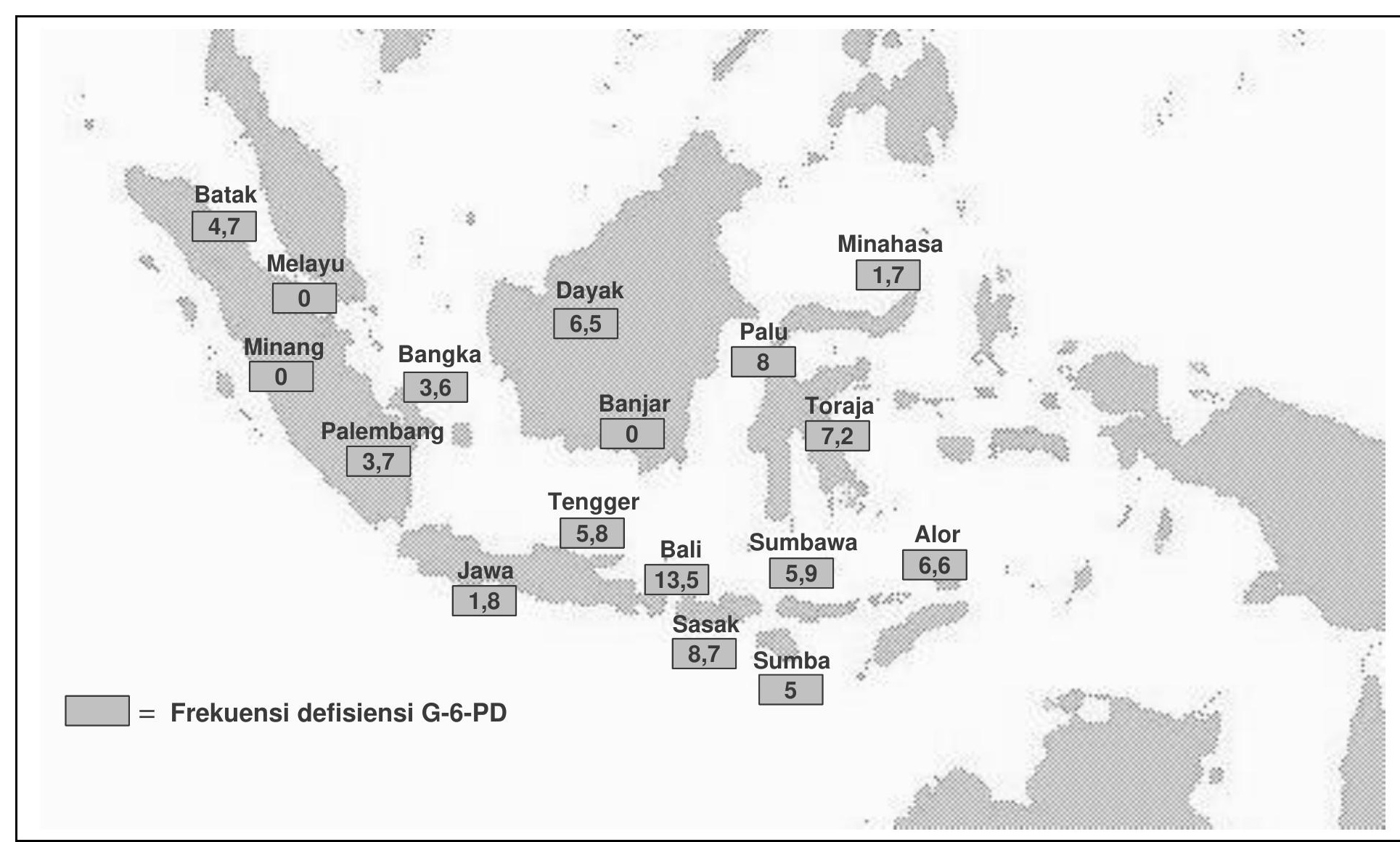

Gambar 3. Distribusi pengemban defisiensi G-6-PD pada berbagai populasi di Indonesia.

Secara keseluruhan hasil penelitian menunjukkan bahwa baik pada metode fluoresensi UV, formazan ring spot test maupun spektrofotometrik adalah sama baik pada kelompok LA maupun kelompok NA. Hasil tersebut menunjukkan bahwa ketiga teknik yang digunakan sama akuratnya dan dapat berdiri sendiri, sehingga untuk penelitian selanjutnya cukup menggunakan salah satu dari ke tiga teknik tersebut untuk menghemat waktu dan biaya. Berdasarkan pengalaman dari penelitian ini, teknik formazan ring spot test dapat dijadikan pilihan utama, karena lebih murah dari kedua teknik lainnya. Selain itu formazan ring spot test juga dapat membedakan secara jelas antara sampel normal dengan defisiensi G-6-PD LA maupun defisiensi G-6-PD NA. Sebelumnya memang telah dilaporkan oleh Fujii (1994), bahwa dengan teknik formazan ring spot test sendiri, jika dilakukan dengan baik diyakini dapat mencapai akurasi 90\% di lapangan. Dengan dilengkapi dengan dua teknik lainnya, maka data yang diperoleh dari penelitian in dianggap cukup akurat.

Terdapatnya jumlah individu perempua pengemban G-6-PD NA hampir sama denga individu laki-laki, padahal gen G-6-PI terangkai X, dapat dijelaskan dengan hipotesi Lyon tentang in-aktivasi salah satu kromosom $\mathrm{X}$ pada individu perempuan secara random Artinya, walaupun individu perempua mempunyai dua kromosom $X$, hanya salah sat kromosom saja yang beraktivitas, sama halny dengan laki-laki. Fenomena ini jelas terliha pada rata-rata aktivitas enzim G-6-PD pad individu normal (Tabel 2), ternyata baik pad kelompok perempuan maupun laki-lak mempunyai aktivitas yang sama atau ad "kesetaraan dosis" walaupun laki-laki hany mempunyai satu kromosom X.

Distribusi defisiensi G-6-PD pad berbagai populasi di Indonesia mengikuti pol klinal tertentu, gen mutan ini dijumpai pad semua populasi di Sunda Kecil denga frekuensi 5 - 13,5\% dan frekuensi tertingg dijumpai di Bali $(13,5 \%)$ seperti yang terter 
pada Gambar 3. Penelitian terpisah yang dilakukan terhadap distribusi ovalositosis menunjukkan ada ko-eksistensi keberadaan kedua kelainan eritrosit tersebut di Indonesia, di mana pada populasi yang rendah frekuensi hemoglobinopatinya akan meningkat frekuensi gen G-6-PD atau ovalositosisnya (Lanni, 2002). Sebaliknya pada populasi di wilayah Indonesia bagian Barat, keberadaan defisiensi G-6-PD lebih rendah karena memang pada wilayah ini, keberadaan hemoglobinopati (thalassemia dan Hb-E) cukup tinggi.

Baik hemoglobinopati, G-6-PD maupun ovalositosis, telah dilaporkan mempunyai keuntungan selektif terhadap plasmodium malaria, sehingga keberadaan gen-gen mutan ini memang dibutuhkan sebagai mekanisme alam untuk menangkis malaria. Tingginya frekuensi defisiensi G-6-PD pada daerah Sunda Kecil dapat dimengerti karena sebagian besar wilayah Sunda Kecil merupakan daerah hiperendemik malaria. Pada individu yang mengemban defisiensi G-6-PD lebih resisten terhadap plasmodium malaria dibandingkan individu normal. Hal ini disebabkan karena pada eritrosit yang defisiensi G-6-PD hanya mengandung sedikit NADPH sebagai sumber energi, dan plasmodium tidak dapat bertahan hidup pada eritrosit tersebut.

\section{Kesimpulan}

Prevalensi defisiensi G-6-PD cukup tinggi pada berbagai populasi di Indonesia dengan frekuensi 3 - 13,5\%. Frekuensi tertinggi dijumpai pada populasi Bali yang mencapai $13,5 \%$.

\section{Ucapan terima kasih}

Penulis mengucapkan banyak terima kasih kepada Prof. dr. Sangkot Marzuki MSc, PhD, DSc, Prof. Dr. dr. HM Ismadi dan Prof. dr. Abdul Salam M. Sofro, PhD yang telah banyak memberi bimbingan selama penelitian berlangsung.

\section{Daftar Pustaka}

Beutler E. 1993. Study of glucose-6-phosphate dehydrogenase: history and molecular biology. Am. J. Hematol. 42 : 53 - 58.

Fujii H. 1994. A new simple screening method for glucose-6-phosphate dehydrogenase deficiency. Acta. Hematol. Jpn. 47:186-188.

Ganczakowski M., Town M., Bowden D.K., et al.,. 1995. Multiple glucose-6-phosphate dehydro-genase deficient variants correlate with malaria endemicity in the Vanuatu archipelago (South-western Pacific). Am. J. Hum. Genet. 56: 294-301.

Hirono A., Forman L. and Beutler E. 1977. Enzymatic diagnosis in non-spherocytic hemolytic anemia. Medicine (Baltimore). 67 (2) : 110-117.

Lanni F. 2002. Heterogenitas Molekular Gena Globin- $\beta$ di Indonesia : Kaitannya dengan Pola Penyebaran Thalassemia- $\beta$ serta Hubungan Genetik antar Populasi di Indonesia. Disertasi S-3, Fakultas Kedokteran UGM, Yogyakarta.

Luzzatto L. 1979. Genetics of red cells and susceptibility to malaria. Blood. 54 : 961976.

Luzzatto L. 1995. About hemoglobin, G-6-PD and parasites in red cells. Expriencia. 51 : 206208.

Luzzatto L. and Gordon-Smith E.C. 1999. Inherited haemolytic anaemias in Hoffbrand A.V., Lewis S.M. and Tuddenham E.G.D. (eds); Postgraduate Haematology $4^{\text {th }}$ edn. Butterwoth-Heinemann Int. Publ. Oxford.

Martini G., Toniolo D., Vulliamy T. et al, 1986. Structural analysis of the X-linked gene encoding human glucose-6-phospate dehydrogenase. EMBO J . 5 (8): 1849-1855.

Mehta A.B..1994. Glucose-phosphate dehydrogenase deficiency. Postgrad. Med. J. 70:871877.

Ruwende C., Khoo S.C. and Snow R.W. 1995. Natural selection of hemi- and heterozygotes for G-6-PD deficiency in Africa by resistance to severe malaria. Nature. 376:246-249. 
Soemantri A.G., Saha S., Saha N. et al., 1995. Molecular variants of red cells glucose-6phosphate dehydro-genase deficiency in central Java, Indonesia. Hum. Hered..45:346-350.

Suhartati, Martini T., Shirakawa T. and Nishiyama K. 2000. Glucose 6 phosphate dehydrogenase (G-6-PD) deficiency variants in isolated small islands in eastern Indonesia. Asian Symposium in Neonatology. Yogyakarta.
Surodi R., Monitja H.E. and Munthe B.G. 1979. G 6-PD deficiency in the Dr. Cipt Mangunkusumo General Hospital. Pediat Indonesian.19:30-40.

Vulliamy T., Beutler E. and Luzatto L. 1992. Th molecular basis of glucose-6-phosphat dehydrogenase deficiency. Trend Genet. (4):138-143. 